\title{
REAL TIME ASSESSMENT OF 500-KVA, 11/0.415 KV DISTRIBUTION TRANSFORMER SITUATED AT BELLS UNIVERSITY OF TECHNOLOGY, OTA, OGUN STATE USING FLUKE 435 SERIES II
}

\author{
AMOLE ABRAHAM OLATIDE ${ }^{*}$, OKUSAGA KAZIM IDOWU1, ODEKUNLE \\ OLUFEMI OLANREWAJU ${ }^{2}$, ODITA IKECHUKWU JOSEPH ${ }^{2}$ \\ ${ }^{I}$ Department of Electrical, Electronic and Computer Engineering, Bells University of \\ Technology, Ota, Ogun State, Nigeria \\ ${ }^{2}$ Eko Electricity Distribution Company, Lagos State, Nigeria
}

\begin{abstract}
Distribution transformer being major equipment in utility companies deserves to be routinely scrutinized for its performance with a view to ensure continuous supply of energy to end-users as well as to sustain improved revenue collection by the utility company. Presented in this paper is the real time assessment of 500-kVA, 11/0.415 kV distribution transformer situated at Bells University of Technology, Ota, Ogun State using power quality and energy analyzer equipment. The parameters measured on real time include phase to neutral voltage, phase to phase voltage, root mean square and peak current, frequency, active power, reactive and apparent power and line power factor. The assessment revealed wide variation of system voltages far from the standard, however, the line power factor and as well as frequency of operation was observed to be within the standard. Based on this analysis, several findings and appropriate recommendations were suggested to improve the supply of energy in the study area. It is hope that the findings of this research will be of immense benefit to distribution engineers at the Department of works in Bells University of Technology, Ota for field compliance.
\end{abstract}

Keywords: apparent power, distribution transformer, power factor, reactive power, real power

\section{INTRODUCTION}

Distribution transformer is a critical component that can be described as the heart-center of power distribution networks [1], its failure can result into spending of millions of naira to bring it back to health status aside the accompanying prolong downtime. Distribution transformer, therefore required extreme care, if end-users of electricity will enjoy reliable energy that will enhance the ease with which their day to day activities are being carried out.

Failure of distribution transformer most especially in a confined environment like University setting could paralysis the both academic and administrative activities unreasonably for a prolong period of time. Under normal operating conditions as specified by the manufacturers, distribution transformers are known to enjoy relatively long-life span [2], averagely its life span ranges from 20 to 25 years [3]. This kind of transformer is robust and highly susceptible to failure over time due to old age, poor insulation, deterioration of cellulose as well as poor

\footnotetext{
* Corresponding author, email: latidassah@gmail.com

(C) 2020 Alma Mater Publishing House
} 
dielectric strength of the oil in addition to overloading and voltage unbalance for a protracted period of time [2, 46]. Real time assessment of the state of distribution transformer is beneficial for continuous supply of energy to the end-users, with this assessment; various abnormal conditions capable of shortening distribution transformer life-span can be easily identified and appropriate preventive measures can promptly be taken than engaging in corrective maintenance after failure has occurred. Parameters of interest in real time assessment of distribution transformer are root mean square voltage and current (single and three phase), active power, apparent power, reactive power, power factor and frequency of operation. Power quality and energy analyzer equipment such as Fluke 435 Series II is endowed with ability to measure this parameter on real time [7].

This paper presents real time assessment of $500 \mathrm{kVA}, 11 / 0.415 \mathrm{kV}$ distribution transformer situated at Bells University of Technology, Ota, Ogun State using Fluke 435 Series II. The aim of this assessment is to determine the operating state of this transformer and make appropriate recommendations to works department at Bell University of Technology on the field for compliance with a view to prevent unnecessary interruptions capable of causing embarrassing acute power supply to this world-class university.

\section{METHODOLOGY}

Power Quality and Energy Analyser equipment -Fluke 435 Series II- is the backbone of this assessment. It was connected with an on-line distribution transformer $(500-\mathrm{kVA}, 11 / 0.415 \mathrm{~V})$ to take measurement of parameters such as RMS voltage (Phase to Phase) magnitude, RMS voltage (Phase to Neutral), peak voltage, RMS current, peak current, frequency, active power, apparent power, reactive power, and power factor. The total duration of analysis spans two hours, thirteen (13) different readings were taken and it was captured at a time interval of ten (10) minutes. Fluke 435 Series II has two sets of probes; one is voltage probes with crocodile clip and the other is current probes with inbuilt current transformer (CT). The procedural steps for connecting Fluke 435 Series II equipment on the low voltage $(\mathrm{LV})$ side of the transformer to take the above parameters of interest are as given thus.

\section{Voltage probes connection}

Step I: The green probe is connected to the earth terminal/ earth wire of the low voltage side of the transformer. Step II: Connect the red probe to red phase, yellow probe to yellow phase, blue probe to blue phase and lastly, neutral probe to neutral.

\section{Current probes connection}

Step I: The probe is connected round each cable with arrow of the current transformer facing down or alternatively in the direction of the flow of current.

Step II: Connect red phase cable, yellow phase cable, blue phase cable and also neutral cable.

The equipment will power up, therefore correct readings of the desired parameters will be display via liquid crystal display (LCD) display of Fluke 435 Series II. Figure 1 showed the set-up for the real time data capturing using Fluke 435 Series II while the flow procedure for this is as depicted with Figure 2.

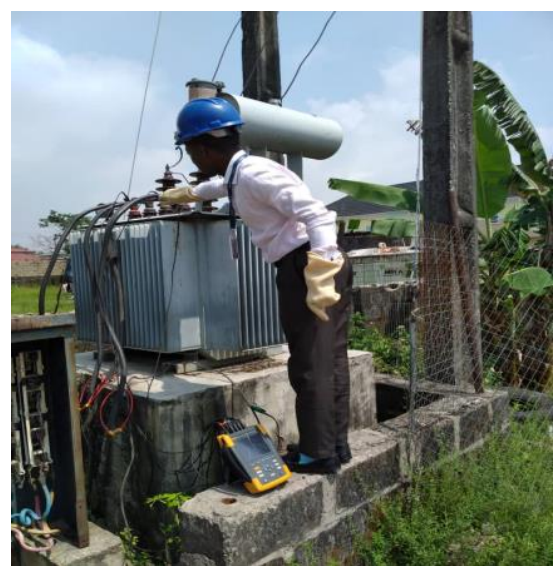

Fig. 1. Set-up for the real time data capturing using Fluke 435 Series II at Bells University of Technology, Ota, Ogun state. 

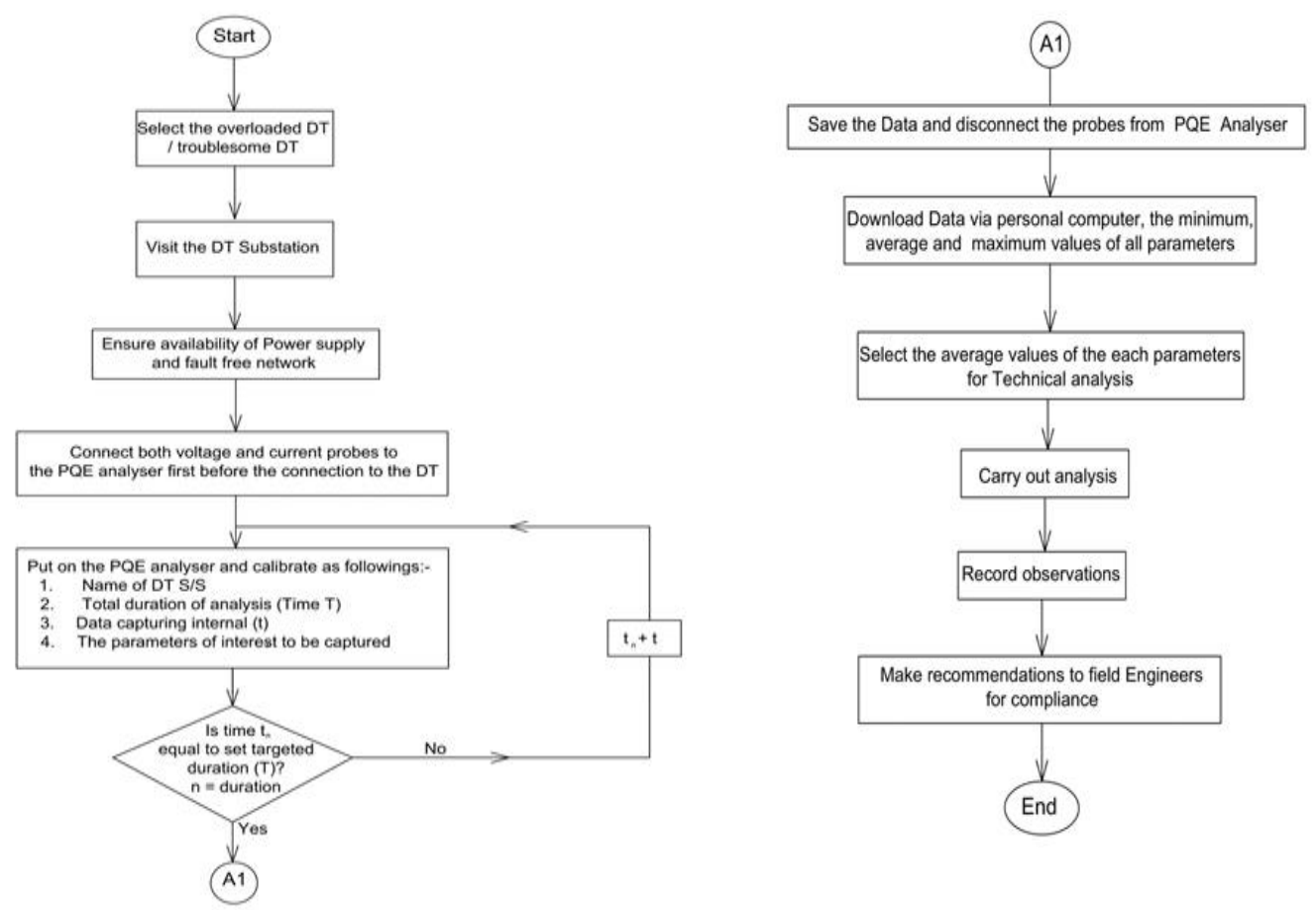

Fig. 2. Flow chart for the real time assessment.

The following are relevant mathematical relations which are perquisite to understanding this work. The relationships that exist between peak and root mean square voltage and current are given by equations (1) and (2) thus:

$$
\begin{aligned}
& V_{r m s}=\frac{V_{p}}{\sqrt{2}} \\
& I_{r m s}=\frac{I_{p}}{\sqrt{2}}
\end{aligned}
$$

Also, for star- connected transformer:

$$
\begin{gathered}
I_{L}=I_{p} \\
V_{p}=\frac{V_{L}}{\sqrt{3}}
\end{gathered}
$$

Similarly, for delta-connected transformer:

$$
\begin{aligned}
& V_{L}=V_{p} \\
& I_{p}=\frac{I_{L}}{\sqrt{3}}
\end{aligned}
$$

where $V_{r m s}$ are root mean square voltage and $V_{p}$ is peak voltage both in volt, $I_{r m s}$ is root mean square current and $I_{p}$ is peak current both in Ampere, $I_{L}$ is line current and $I_{p}$ is phase current both in Ampere, $V_{L}$ is line voltage, $V_{p}$ is phase voltage both in volt.

The real power ( $\mathrm{P}$ in watt) is expressed as:

$$
P=\sqrt{3} I V \cos \theta
$$

The reactive power ( $\mathrm{Q}$ in Volt-Ampere): 


$$
Q=\sqrt{3} I V \sin \theta
$$

The apparent power ( $\mathrm{S}$ in $\mathrm{VAr}$ ) is obtained as:

$$
S=\sqrt{P+Q}
$$

The power factor is obtained thus:

$$
P f=\cos \theta
$$

\section{RESULT AND DISCUSSION}

Table 1 showed the values obtained on real time with Fluke 435 Series II for phase to phase voltage. The value ranges from 374.30 to $389.42 \mathrm{~V}$ and the expected phase to phase voltage should be $415 \mathrm{~V}$; obviously these values are below the standard. Also, the phase to neutral voltage recorded as shown in Table 2, it ranges from $216.4 \mathrm{~V}$ to $225.98 \mathrm{~V}$, and by Nigerian standard and specification, these values fall below the conventional value of $230 \mathrm{~V}$. Similarly, there is a significant variation in the value obtained for both peak and root mean square current as shown in Table 3 and 4 . The implication of this is that the consumer connected loads at the tail end of the LV reticulations stands to be extremely low due to significant voltage drop along the line. We could infer that the load on this transformer is unbalance because the 3 phases are not having the same values neither are these values relatively closed.

Table 1. Root Mean Square Voltage (Phase to Phase).

\begin{tabular}{|l|c|c|c|}
\hline Time & $\begin{array}{c}\text { Vrms ph-ph L12 } \\
\text { Avg }\end{array}$ & $\begin{array}{c}\text { Vrms ph-ph } \\
\text { L23 Avg }\end{array}$ & $\begin{array}{c}\text { Vrms ph-ph L31 } \\
\text { Avg }\end{array}$ \\
\hline 9:00:10 PM.358 & 388.24 & 389.42 & 383.06 \\
\hline 9:10:10 PM.358 & 382.92 & 384.68 & 378.16 \\
\hline 9:20:10 PM.358 & 378.38 & 380.64 & 374.30 \\
\hline 9:30:10 PM.358 & 378.38 & 379.80 & 373.68 \\
\hline 9:40:10 PM.358 & 379.44 & 382.08 & 375.22 \\
\hline 9:50:10 PM.358 & 380.20 & 382.94 & 376.42 \\
\hline 9:59:10 PM.358 & 384.76 & 386.58 & 381.44 \\
\hline 10:00:10 PM.358 & 384.34 & 386.22 & 381.08 \\
\hline 10:10:10 PM.358 & 382.36 & 382.72 & 376.24 \\
\hline 10:20:10 PM.358 & 379.82 & 381.22 & 374.58 \\
\hline 10:30:10 PM.358 & 383.98 & 384.14 & 377.52 \\
\hline 10:40:10 PM.358 & 382.00 & 382.90 & 376.28 \\
\hline 10:50:10 PM.358 & 385.98 & 388.14 & 382.98 \\
\hline
\end{tabular}

Table 2. Root Mean Square Voltage (Phase to Neutral).

\begin{tabular}{|l|c|c|c|c|}
\hline Time & $\begin{array}{c}\text { Vrms ph-N L1N } \\
\text { Avg }\end{array}$ & $\begin{array}{c}\text { Vrms ph-N L2N } \\
\text { Avg }\end{array}$ & $\begin{array}{c}\text { Vrms ph-N L3N } \\
\text { Avg }\end{array}$ & $\begin{array}{c}\text { Vrms ph-N } \\
\text { Avg }\end{array}$ \\
\hline 9:00:10 PM.358 & 222.14 & 225.98 & 222.02 & 3.76 \\
\hline 9:10:10 PM.358 & 219.04 & 223.10 & 219.36 & 3.56 \\
\hline 9:20:10 PM.358 & 216.46 & 220.72 & 217.14 & 3.84 \\
\hline 9:30:10 PM.358 & 216.40 & 220.44 & 216.64 & 4.00 \\
\hline 9:40:10 PM.358 & 216.92 & 221.50 & 217.88 & 4.06 \\
\hline 9:50:10 PM.358 & 217.40 & 221.92 & 218.62 & 4.16 \\
\hline 9:59:10 PM.358 & 220.52 & 223.42 & 221.62 & 0.54 \\
\hline 10:00:10 PM.358 & 220.28 & 223.18 & 221.42 & 12.94 \\
\hline 10:10:10 PM.358 & 218.68 & 222.26 & 218.02 & 10.84 \\
\hline 10:20:10 PM.358 & 217.26 & 221.24 & 217.14 & 11.08 \\
\hline 10:30:10 PM.358 & 219.54 & 223.26 & 218.64 & 12.20 \\
\hline 10:40:10 PM.358 & 218.42 & 222.32 & 218.12 & 15.52 \\
\hline 10:50:10 PM.358 & 221.26 & 224.20 & 222.58 & 0.560 \\
\hline
\end{tabular}


Table 5 showed the system frequency as acquired with the aid of Fluke 435 Series II, the frequency is measured to be between $50.23 \mathrm{~Hz}$ to $50.55 \mathrm{~Hz}$, hence the operation is considered stable. However, $\pm 2 \%$ of $50 \mathrm{~Hz}$ frequency is allowed by standard in power system operation. Furthermore, Table 6, 7 and 8 present the active, reactive and apparent power acquired with the Fluke 435 on real time, close observation of these Tables showed that the peak active power, apparent power and reactive power are $211.980 \mathrm{~kW}$ at 10:30:10 pm, 222.06 kVA at 10:30:10pm and $55.92 \mathrm{kVAr}$ at 10:30:10pm respectively. This implies that the percentage of reactive power to active power in this network is $73.62 \%$ which contradict the allowable percentage of $5 \%$ by IEEE regulation.

Table 3. Root Mean Square Current.

\begin{tabular}{|l|c|c|c|c|}
\hline Time & Current L1 Avg & Current L2 Avg & Current L3 Avg & Current N Avg \\
\hline 9:00:10 PM. & 162.2 & 127.20 & 202.90 & 92.60 \\
\hline 9:10:10 PM. & 178.7 & 140.70 & 219.60 & 92.00 \\
\hline 9:20:10 PM & 202.9 & 132.70 & 216.50 & 106.7 \\
\hline 9:30:10 PM & 158.6 & 121.30 & 186.10 & 96.80 \\
\hline 9:40:10 PM & 186.6 & 128.60 & 203.90 & 98.10 \\
\hline 9:50:10 PM & 194.7 & 130.00 & 193.60 & 96.10 \\
\hline 9:59:10 PM & 0.200 & 0.10 & 0.20 & 0.10 \\
\hline 10:00:10 PM & 0.200 & 0.10 & 0.20 & 0.10 \\
\hline 10:10:10 PM & 289.00 & 312.10 & 383.40 & 98.50 \\
\hline 10:20:10 PM & 302.50 & 290.40 & 381.00 & 111.70 \\
\hline 10:30:10 PM & 294.10 & 306.50 & 397.2 & 113.80 \\
\hline 10:40:10 PM & 303.40 & 305.70 & 387.5 & 103.20 \\
\hline 10:50:10 PM & 0.200 & 0.10 & 0.20 & 0.10 \\
\hline
\end{tabular}

Table 4. Peak Current.

\begin{tabular}{|l|c|c|c|c|}
\hline Time & $\begin{array}{c}\text { Active Power } \\
\text { L1N Avg }\end{array}$ & $\begin{array}{c}\text { Active Power } \\
\text { L2N Avg }\end{array}$ & $\begin{array}{c}\text { Active Power } \\
\text { L3N Avg }\end{array}$ & $\begin{array}{c}\text { Active Power } \\
\text { Total Avg }\end{array}$ \\
\hline 9:00:10 PM.358 & 34860 & 27880 & 42800 & 105540 \\
\hline 9:10:10 PM.358 & 38340 & 30780 & 46380 & 115500 \\
\hline 9:20:10 PM.358 & 43180 & 28580 & 45380 & 117120 \\
\hline 9:30:10 PM.358 & 33680 & 25880 & 37860 & 97440 \\
\hline 9:40:10 PM.358 & 39660 & 27700 & 42600 & 109980 \\
\hline 9:50:10 PM.358 & 41500 & 28060 & 40620 & 110160 \\
\hline 9:59:10 PM.358 & 20 & 0 & 20 & 60 \\
\hline 10:00:10 PM.358 & 20 & 0 & 20 & 60 \\
\hline 10:10:10 PM.358 & 61400 & 68180 & 79240 & 208860 \\
\hline 10:20:10 PM.358 & 63880 & 63160 & 78760 & 205800 \\
\hline 10:30:10 PM.358 & 62740 & 67420 & 81820 & 211980 \\
\hline 10:40:10 PM.358 & 64340 & 66960 & 80300 & 211620 \\
\hline 10:50:10 PM.358 & 20 & 20 & 20 & 60 \\
\hline
\end{tabular}

Table 5. Frequency.

\begin{tabular}{|l|c|}
\hline Time & Frequency Avg \\
\hline 9:00:10 PM.358 & 50.363 \\
\hline 9:10:10 PM.358 & 50.231 \\
\hline 9:20:10 PM.358 & 50.244 \\
\hline 9:30:10 PM.358 & 50.262 \\
\hline 9:40:10 PM.358 & 50.359 \\
\hline 9:50:10 PM.358 & 50.416 \\
\hline 9:59:10 PM.358 & 50.411 \\
\hline 10:00:10 PM.358 & 50.412 \\
\hline 10:10:10 PM.358 & 50.419 \\
\hline 10:20:10 PM.358 & 50.464 \\
\hline 10:30:10 PM.358 & 50.55 \\
\hline 10:40:10 PM.358 & 50.515 \\
\hline 10:50:10 PM.358 & 50.518 \\
\hline
\end{tabular}

Table 9 presented the lines power factor; it was observed that these values are satisfactorily within the minimum value of 0.94 and maximum value of 0.99 across the three phases. The measured value for the network power 
factor ranges from 0.95 to 0.96 and the overall average network power factor was estimated to 0.97. Considering the average apparent power value of $144.81 \mathrm{kVA}$ loading of the Distribution transformer with its 500kVA rated capacity, it implies the percentage loading of the distribution transformer stood at $28.06 \%$ as at the time of real time measurement. However, it is important to note that the readings were taken at the off-peak load period of the DT substation and also the most loaded upriser was out due to fault, but the loads on it has a greater value of reactive power. It is expected that the reactive power presence would be higher at peak load period with appreciable consequence of power factor value reduction.

Table 6. Active Power.

\begin{tabular}{|l|c|c|c|c|}
\hline Time & $\begin{array}{c}\text { Active Power } \\
\text { L1N Avg }\end{array}$ & $\begin{array}{c}\text { Active Power } \\
\text { L2N Avg }\end{array}$ & $\begin{array}{c}\text { Active Power } \\
\text { L3N Avg }\end{array}$ & $\begin{array}{c}\text { Active Power } \\
\text { Total Avg }\end{array}$ \\
\hline 9:00:10 PM.358 & 34860 & 27880 & 42800 & 105540 \\
\hline 9:10:10 PM.358 & 38340 & 30780 & 46380 & 115500 \\
\hline 9:20:10 PM.358 & 43180 & 28580 & 45380 & 117120 \\
\hline 9:30:10 PM.358 & 33680 & 25880 & 37860 & 97440 \\
\hline 9:40:10 PM.358 & 39660 & 27700 & 42600 & 109980 \\
\hline 9:50:10 PM.358 & 41500 & 28060 & 40620 & 110160 \\
\hline 9:59:10 PM.358 & 20 & 0 & 20 & 60 \\
\hline 10:00:10 PM.358 & 20 & 0 & 20 & 60 \\
\hline 10:10:10 PM.358 & 61400 & 68180 & 79240 & 208860 \\
\hline 10:20:10 PM.358 & 63880 & 63160 & 78760 & 205800 \\
\hline 10:30:10 PM.358 & 62740 & 67420 & 81820 & 211980 \\
\hline 10:40:10 PM.358 & 64340 & 66960 & 80300 & 211620 \\
\hline 10:50:10 PM.358 & 20 & 20 & 20 & 60 \\
\hline
\end{tabular}

Table 7. Reactive Power.

\begin{tabular}{|l|c|c|c|c|}
\hline Time & $\begin{array}{c}\text { Reactive Power } \\
\text { L1N Avg }\end{array}$ & $\begin{array}{c}\text { Reactive Power } \\
\text { L2N Avg }\end{array}$ & $\begin{array}{c}\text { Reactive Power } \\
\text { L3N Avg }\end{array}$ & $\begin{array}{c}\text { Reactive Power } \\
\text { Total Avg }\end{array}$ \\
\hline 9:00:10 PM.358 & 7880 & 3860 & 12500 & 24420 \\
\hline 9:10:10 PM.358 & 8020 & 3360 & 12280 & 23820 \\
\hline 9:20:10 PM.358 & 8300 & 3400 & 11160 & 23040 \\
\hline 9:30:10 PM.358 & 6520 & 3420 & 12600 & 22680 \\
\hline 9:40:10 PM.358 & 8300 & 3620 & 11520 & 23640 \\
\hline 9:50:10 PM.358 & 8500 & 3620 & 10540 & 22800 \\
\hline 9:59:10 PM.358 & 40 & 0 & 20 & 60 \\
\hline 10:00:10 PM.358 & 40 & 0 & 20 & 60 \\
\hline 10:10:10 PM.358 & 15460 & 11900 & 27060 & 54720 \\
\hline 10:20:10 PM.358 & 15940 & 10240 & 25740 & 52200 \\
\hline 10:30:10 PM.358 & 15820 & 10140 & 29580 & 55920 \\
\hline 10:40:10 PM.358 & 16460 & 10060 & 26900 & 53700 \\
\hline 10:50:10 PM.358 & 40 & 0 & 20 & 60 \\
\hline
\end{tabular}

Table 8. Apparent Power.

\begin{tabular}{|l|c|c|c|c|}
\hline Time & $\begin{array}{c}\text { Apparent Power } \\
\text { L1N Avg }\end{array}$ & $\begin{array}{c}\text { Apparent Power } \\
\text { L2N Avg }\end{array}$ & $\begin{array}{c}\text { Apparent Power } \\
\text { L3N Avg }\end{array}$ & $\begin{array}{c}\text { Apparent Power } \\
\text { Total Avg }\end{array}$ \\
\hline 9:00:10 PM & 35740 & 28680 & 44920 & 111480 \\
\hline 9:10:10 PM & 39140 & 31400 & 48160 & 120720 \\
\hline 9:20:10 PM & 43920 & 29280 & 46980 & 122760 \\
\hline 9:30:10 PM & 34320 & 26720 & 40300 & 102960 \\
\hline 9:40:10 PM & 40460 & 28480 & 44400 & 115500 \\
\hline 9:50:10 PM & 42320 & 28840 & 42320 & 115380 \\
\hline 9:59:10 PM & 40 & 20 & 40 & 120 \\
\hline 10:00:10 PM & 40 & 20 & 40 & 120 \\
\hline 10:10:10 PM & 63200 & 69360 & 83580 & 217860 \\
\hline 10:20:10 PM & 65720 & 64240 & 82720 & 214500 \\
\hline 10:30:10 PM & 64560 & 68420 & 86800 & 222060 \\
\hline 10:40:10 PM & 66260 & 67960 & 84520 & 220380 \\
\hline 10:50:10 PM & 40 & 40 & 40 & 120 \\
\hline
\end{tabular}


Table 9. Power Factor.

\begin{tabular}{|l|c|c|c|c|}
\hline Time & $\begin{array}{c}\text { Power Factor } \\
\text { L1N Avg }\end{array}$ & $\begin{array}{c}\text { Power Factor } \\
\text { L2N Avg }\end{array}$ & $\begin{array}{c}\text { Power Factor } \\
\text { L3N Avg }\end{array}$ & $\begin{array}{c}\text { Power Factor } \\
\text { Total Avg }\end{array}$ \\
\hline 9:00:10 PM.358 & 0.98 & 0.97 & 0.95 & 0.95 \\
\hline 9:10:10 PM.358 & 0.98 & 0.98 & 0.96 & 0.96 \\
\hline 9:20:10 PM.358 & 0.98 & 0.98 & 0.97 & 0.95 \\
\hline 9:30:10 PM.358 & 0.98 & 0.97 & 0.94 & 0.95 \\
\hline 9:40:10 PM.358 & 0.98 & 0.97 & 0.96 & 0.95 \\
\hline 9:50:10 PM.358 & 0.98 & 0.97 & 0.96 & 0.95 \\
\hline 9:59:10 PM.358 & 0 & 0 & 0 & 0.2 \\
\hline 10:00:10 PM.358 & 0 & 0 & 0 & 0.27 \\
\hline 10:10:10 PM.358 & 0.97 & 0.98 & 0.95 & 0.96 \\
\hline 10:20:10 PM.358 & 0.97 & 0.98 & 0.95 & 0.96 \\
\hline 10:30:10 PM.358 & 0.97 & 0.99 & 0.94 & 0.95 \\
\hline 10:40:10 PM.358 & 0.97 & 0.99 & 0.95 & 0.96 \\
\hline 10:50:10 PM.358 & 0 & 0 & 0 & 0.24 \\
\hline
\end{tabular}

\section{CONCLUSIONS}

This paper presented comprehensive real time assessment of 500-kVA, 11/0.415 kV distribution transformer situated at Bells University of Technology, Ota, Ogun State using Fluke 435 Series II. The parameters measured include rms voltage and current, peak voltage and current, active power, reactive power, apparent power and power factor. The assessment showed that there are wide variations of measured values compared with the standard expected values. The system frequency and line power factor were observed to be within the acceptable standard which implies a stable operation. Based on this assessment the following recommendations are therefore necessary for operation compliance to standard:

- due to the load imbalances in the distribution transformer substation which caused neutral current to be high as shown in Table 3, it is therefore a thing of necessity for the operation Engineers to comb the network and to approximately balance phases load;

-the average power factor of the distribution transformer substation is 0.96 as shown in Table 9; at point where these value falls below 0.85 , installation of appropriate size of capacitor bank is required for the correction of PF to desire specification ( 0.9 to 0.95$)$;

- it was observed that the $500 \mathrm{~mm} 2 \mathrm{X} 1 \mathrm{LV}$ cable was excessively hot indicating the presence of circulatory current which can potentially damage the cable as well as increasing the loss on the transformer; hence appropriate cable size should be used as replacement;

- the transformer was observed to be leaking oil from the secondary bushing, this has resulted in excessive humming sound from the distribution transformer hence the need for comprehensive servicing and topping of the oil;

- similarly, the secondary neutral was not earthed, hence proper grounding of the neutral is recommended;

- the yellow phase lightning arrester was not connected which will allow the overvoltage to pass through the distribution transformer rather than being conducted to ground, hence the use of silicon lightning arrester is thus recommended.

\section{ACKNOWLEDGEMENT}

The authors acknowledged the Management of Bells University of Technology, Ota, Ogun State, Nigeria for granting the permission to carry out the analysis on the University distribution transformer.

\section{REFERENCES}

[1] Ade-Ikuesan, O.O., Okakwu, I.K., Olabode, O.E., Olubanwo, P. O., Design and implementation of a 2-kVA, shell-type, step-down, transformer, Advances in Electrical and Telecommunication Engineering, vol. 1, 2018, p. 111-120.

[2] Jenifer, A., Bharathi, B.R., Shanthi, M. B., Monitoring and protection of distribution transformer using GSM module, International Journal of Engineering and Techniques, vol. 4, no. 1, 2018, p. 565-569.

[3] Poyser, T.D., An on-line microprocessor-based transformer analysis system to improve the availability and utilization of power transformers, IEEE Transaction on Power Apparatus and Systems, vol. 102, 1983, p. 957-962. 
[4] Avinash, N.A., Gajanan, C.J., Makarand, S.B., Tutakne, D.R., Remote condition monitoring system for distribution transformer, IEEE Transaction on Power Delivery, vol. 18, no. 1, 2014, p. 4-13.

[5] Chan, W.L, So, A.T.P., Lai, L., Interment based transmission substation monitoring, IEEE Transaction on Power Systems, vol. 14, no. 1, 1999, p.293-298.

[6] Bengtsson, C., Status and trends in transformer monitoring, IEEE Transactions on Power Delivery, vol. 11, no. 3, 1996, p. 10-20.

[7] Technical Data, Fluke 430 Series II Three-Phase Power Quality and Energy Analyzers, 2018. 